\title{
REALISME SOSIAL DALAM POTRET SEORANG KOMUNIS KARYA SABAR ANANTAGUNA
}

\section{SOCIAL REALISM IN POTRET SEORANG KOMUNIS BY SABAR ANANTAGUNA}

\author{
Elis Susilawati ${ }^{1 *}$, Ismah Rahayu ${ }^{2}$, Akifah Humaira Salsabila ${ }^{3}$, Ahmad Bahtiar ${ }^{4}$ \\ Pendidikan Bahasa dan Sastra Indonesia, UIN Syarif Hidayatullah Jakarta, \\ Indonesia ${ }^{1,2,3,4}$ \\ $\underline{\text { elis.susilawati20@mhs.uinjkt.ac.id }}{ }^{1}$, ismah.rahayu20@mhs.uinjkt.ac.id $^{2}$, \\ akifah.humaira@mhs.uinjkt.ac.id ${ }^{3}$, ahmad.bahtiar@uinjkt.ac.id ${ }^{4}$ \\ *penulis korespondensi
}

\begin{tabular}{ll}
\hline Info Artikel & ABSTRAK \\
\hline Article history: & Puisi Potret Seorang Komunis karya Sabar Anantaguna telah mendapatkan \\
Received: & bentuk dan pengucapan yang tepat sehingga menjadi prestasi yang bagus \\
22 June 2021 & dalam sastra realisme sosialis karena tidak terlepas dari latar belakang dan \\
Revised: & ideologi pengarang yang merupakan bagian dari Lekra. Penelitian ini \\
3 December 2021 & bertujuan untuk membahas prinsip realisme sosial yang menjadi pandangan \\
Accepted: & para pengarang Lekra. Metode analisis yang digunakan dalam penelitian ini \\
8 January 2022 & adalah metode penelitian deskriptif kualitatif dan teknik interpretatif. Dalam \\
& pengolahan data dilakukan tahap pendeskripsian dan penganalisisan. \\
Kata kunci: & Penelitian ini menggunakan teori sosiologi sastra, teori realisme sosial dan \\
komunis, puisi, & teori struktural. Hasil dari penelitian Realisme Sosial dalam Potret Seorang \\
realisme sosial, Lekra & Komunis Karya sabar Anantaguna terbukti bahwa prinsip realisme sosial \\
& yang menjadi pandangan para pengarang Lekra yaitu Lekra memiliki \\
& berbagai macam cara yang dilakukan dengan maksud mempertahankan \\
& kekuatan komunis, salah satunya melakukan berbagai teror kepada setiap \\
& golongan untuk bergabung dengan Lekra.
\end{tabular}

\begin{tabular}{ll}
\hline Article Info & ABSTRACT \\
\hline $\begin{array}{l}\text { Article history: } \\
\text { Received: }\end{array}$ & $\begin{array}{l}\text { The poem Potret Seorang Komunis written by Sabar Anantaguna has } \\
\text { obtained the right form and pronunciation. Therefore, it becomes a good } \\
\text { 22 June 2021 } \\
\text { Revised: }\end{array}$ \\
$\begin{array}{l}\text { 3 December 2021 } \\
\text { the author background and ideology who is part of Lekra This study aims to } \\
\text { Accepted: }\end{array}$ & $\begin{array}{l}\text { discuss the social realism principles that becomes the views of the Lekra } \\
\text { a January 2022 }\end{array}$ \\
$\begin{array}{l}\text { taking techniques. In processing data, the stages of description and data } \\
\text { analysis are carried out. This study used sociology literature research, }\end{array}$ \\
Keyword: \\
communist, poem, \\
recial realism, Lekra social teory and structural teory. The result of the research on social \\
realism in Potret Seorang Komunis by Sabar Anantaguna proves that \\
realism social principle becomes the views of Lekra author, namely Lekra, \\
had various ways that were carried out to maintain communist power, one \\
of which carried out various terrors to every groups in order to join Lekra.
\end{tabular}




\section{PENDAHULUAN}

Pada tahun 1950, muncul sebuah organisasi yang bernama Lekra (Lembaga Kebudayaan Rakyat). Lekra didirikan atas pemikiran M.S. Ashar, D.N. Aidit, A.S. Dharta, dan Nyoto pada Kamis, 17 Agustus 1950. Lekra memiliki beberapa divisi, yaitu divisi seni suara, seni rupa, seni drama, sastra, filsafat, film, dan olahraga. Kongres Nasional Pertama Lekra yang diadakan di Solo, tanggal 22-28 Januari 1959 berhasil mengesahkan Lembaga Kebudayaan Rakyat Mukadimah. Dalam Mukadimah tersebut disampaikan bahwa Lekra membantah pendapat mengenai kesenian dan ilmu bisa terlepas dari masyarakat, Lekra mendorong kebenaran dengan menolak sifat anti-kemanusiaan dan anti-sosial dari kebudayaan bukan-rakyat, Lekra bekerja untuk membantu pembentukan manusia baru yang memiliki segala kemampuan untuk memajukan dirinya dalam perkembangan kepribadian yang bersegi banyak dan harmonis serta Lekra menganjur untuk mempelajari dan memahami pertentanganpertentangan yang berlaku di dalam masyarakat maupun hati manusia. Lekra memiliki dukungan yang kuat terhadap realisme sosial atau paham "seni untuk rakyat".

Realisme sosialis adalah salah satu aliran sosialis yang dominan di Eropa Barat (Habiba, 2018), yang berhubungan dengan sastra dan mengharuskan penulis untuk menyajikan penggambaran yang benar berdasarkan kenyataan. Selain itu, Georg Lukacs berpandangan bahwa realisme adalah teori seni yang mendasarkan pada kontemplasi dialektis antara seniman dengan lingkungan sosialnya (Audriana, 2018). Realisme sosial juga merupakan metode yang dimanfaatkan dalam sastra. Realisme sosialis tidak jauh berbeda dengan sosialisme yaitu berpusat pada negara. Akan tetapi, yang menjadi pembeda dari realisme sosial yaitu memiliki metode tersendiri. Perkembangan politik pada saat itu diberi revolusi oleh sastra dan perjuangannya (Wati, 2018 ).

Paham realisme sosial pernah digunakan dalam beberapa karya sastra, bahkan beberapa diantaranya berkategori anti Muslim. Ciri khas penulisan kaum realisme sosial selalu muncul keadaran suatu kelas mengenai dampak negatif yang ditimbulkan kapitalisme dan mengutamakan kemanusiaan (Muqoddas, 2020). Contoh paham realisme sosial terdapat pada karya Utuy Tatan Sontani Si Kampeng dan karya Pramudya Ananta Toer: Si Manis Bergigi Emas, yang menggambarkan para kyai dan haji sebagai tokoh penghisap rakyat (Bahtiar, 2011). Selain itu, paham realisme sosial juga diterapkan dalam puisi Potret Seorang Komunis karya Sabar Anantaguna untuk menjelaskan pandangan Lekra terhadap prinsip realisme sosial.

Puisi Potret Seorang Komunis dipilih oleh peneliti untuk mengetahui hal penting yaitu realisme sosial yang dimaksud dalam puisi tersebut. Puisi Potret Seorang Komunis juga erat kaitannya dengan Lekra dan menjadi pandangan utama para pengarang yang tergabung dalam organisasinya yang menganut erat prinsip realisme sosial. Realisme sosial yang dikandung dalam puisi Potret Seorang Komunis terjadi pada masa itu tidak lepas dari seorang penulis yang menjadi bagian dari Lekra.

Potret Seorang Komunis merupakan salah satu ragam karya sastra Indonesia, yaitu puisi bergenre elegi. Pramoedya Ananta Toer 
menyatakan bahwa puisi karya Sabar Anantaguna tersebut telah mendapatkan bentuk dan pengucapan yang tepat sehingga menjadi prestasi yang bagus dalam sastra realisme sosialis. Sabar Anantaguna adalah salah satu penyair Lekra yang kuat dalam menyampaikan pesan namun tidak kehilangan semangat kepenyairannya. Puisi yang dihasilkan Sabar Anantaguna merupakan ekspresi dari hasil penghayatan dan pendalaman yang selalu menyentuh hati masyarakat.

Melalui naskah puisi Potret Seorang Komunis dapat kita ketahui prinsip realisme sosial yang menjadi pandangan para pengarang Lekra. Hal tersebut tidak perlu diragukan karena pada proses pembuatannya tidak terlepas dari latar belakang dan ideologi pengarang yang merupakan bagian dari Lekra. Selanjutnya, penelitian ini bertujuan untuk menganalisis dan membahas prinsip realisme sosial yang menjadi pandangan para pengarang Lekra dalam puisi Potret Seorang Komunis. Realisme sosial pandangan Lekra dianalisis dengan melihat keindahan bahasa yang digunakan penulis untuk menyusun kata, larik dan rima dari setiap bait, dan isi serta makna-makna yang terkandung dalam naskah puisi karya Sabar Anantaguna.

Teori yang digunakan untuk menganalisis puisi pada kajian ini adalah sosiologi sastra dan struktural. Sosiologi sastra berasal dari kata sosiologi dan sastra (Bagus, 2018). Sosiologi merupakan ilmu yang membahas tentang perilaku sosial antara individu dengan kelompok. Menurut Mursal Esten, sastra adalah pengungkapan dari fakta artistik dan imajinatif sebagai manifestasi kehidupan manusia dan masyarakat umumnya, melalui bahasa sebagai medium dan memiliki efek positif terhadap kehidupan manusia (Isthifa, 2014). Interaksi dan hubungan sosial yang terdapat dalam suatu karya sastra berusaha dibahas dalam sosiologi sastra. Hal tersebut terjadi karena sastra sering mengungkap perjuangan umat manusia dalam menentukan masa depannya, berdasarkan perasaan, imajinasi, dan instuisi. Dengan demikian, dapat disimpulkan bahwa pendekatan sosiologi sastra membahas secara lebih detail mengenai pola dan perilaku sosial yang tercantum dalam sebuah karya sastra.

Pendekatan sosiologi sastra mengamati karya sastra dari tiga aspek, yaitu dari sudut pandang karya sastra (sosiologi karya sastra), sudut pandang pengarang (sosiologi pengarang), dan sudut pandang pembaca selaku penikmat karya sastra.

Teori struktural turut digunakan dalam penelitian ini. Teori struktural digunakan sebagai langkah awal sebelum melihat aspek sosial yang didapat dalam karya sastra melalui teori sosiologi sastra. (Pradopo, 2010) menyatakan bahwa penelitian yang menggunakan teori struktural tentu berhubungan erat dengan unsur pembangun pada karya sastra itu sendiri, hubungan antar unsur, dan mekanisme antar hubungan yang saling berkaitan. Hal yang dimaksud adalah memahami karya sastra berdasarkan unsur-unsur internal seperti diksi, amanat, imajinasi, gaya bahasa, rima dari setiap bait, larik dan rima dari setiap bait, dan makna yang terkandung di dalamnya.

Dalam penelitian sebelumnya, pernah dilakukan oleh Syahriel A'innur Rifan (2020) dalam jurnalnya yang berjudul "Realisme Sosial dalam Novel Bumi Manusia dan Anak Semua Bangsa Karya Pramoedya Ananta 
Toer" oleh Syahriel, hasil dari kajian tersebut adalah realisme sosial mengemban tanggung jawab atas pendidikan rakyat dalam rangka membangun masyarakat sosialis, sangat berkepentingan untuk memberikan semacam kesadaran sejarah pada rakyat serta sejarah umat manusia selalu berhubungan dengan kelas dan perjuangan kelas (Syahriel, 2020); "Menyoal Realisme Sosial dalam Novel Gadis Pantai Karya Pramoedya Ananta Toer dengan Analisis Strategi Naratif" oleh Rukayah. Dalam kajian tersebut penulis menyebutkan bahwa tokoh tanpa nama memperuncing pertentangan kelas yang ada, bahkan yang menarik masyarakat kelas bawah sendiri juga bertentangan di dalam strata kelasnya sendiri (Rukayah, 2016); "Realisme Sosial Roman Larasati Karya Pramoedya Ananta Toer" oleh P.A. Hambali memberikan simpulan bahwa roman Larasati, merupakan salah satu cara dalam karya sastra untuk memberikan penyadaran, perlawanan, dan penjajahan yang bersifat tidak dapat ditoleransi lagi (Pedi Ahmad, 2011); "Realisme Sosial dan Pertentangan Kelas Sosial dalam Novel Entrok Karya Okky Madasari" oleh Suaib yang memberikan kesimpulan bahwa realisme sosial dalam novel Enterok dipengaruhi beberapa faktor seperti faktor politik, ekonomi, dan pendidikan yang menyebabkan pertentangan kelas dan penindasan yang didominasi oleh lurah, camat, bupati, dan tentara (Suaib, 2016); "Ideologi Kesadaran Kelas dalam Novel Cinta untuk Perempuan dengan Bulir-Bulir Cahaya di Wajahnya Karya Sayfullan (Kajian Marxisme) oleh Anida. Dalam kajian tersebut, penulis menyebutkan bahwa realisme sosial muncul pada saat Indonesia telah merdeka dan terjadi sebuah peperangan dengan Jepang (Wati, 2018).

Gagasan pemecah masalah yang akan digunakan yaitu dengan menguraikan puisi "Potret Seorang Komunis" serta memberikan pandangan yang sesuai dengan lariklariknya. Berdasarkan hasil kajian yang sudah dilaksanakan sebelumnya, Realisme sosial yang ada pada karya sastra selalu menunjukan pertentangan antar golongan, yang menjadi pembeda hanyalah objek dari kajian. Pada penelitian ini sumber data diambil dari puisi Potret Seorang Komunis karya Sabar Anantaguna.

\section{METODE}

Penelitian ini berbentuk penelitian deskriptif kualitatif dengan menggunakan pendekatan sosiologi sastra, teori realisme sosial, dan teori struktural. Fokus dan tujuan dalam penelitian ini adalah untuk mendeskripsikan dan menjelaskan secara mendalam mengenai prinsip realisme sosial dalam Potret Seorang Komunis Karya Sabar Anantaguna. Sumber data primer yang digunakan dalam penelitian ini adalah naskah puisi Potret Seorang Komunis Karya Sabar Anantaguna. Sumber data skunder diperoleh dari referensi yang mendukung analisis data berkaitan dengan sosiologi sastra dan prinsip realisme sosial. Pengumpulan data dilakukan dengan mendeskripsikan mencatat dan menganalisis naskah puisi.

Teknik pengumpulan data dalam penelitian ini, yaitu teknik simak dan catat. Teknik simak dimaksudkan agar Peneliti menyimak puisi Potret Seorang Komunis dan teknik catat digunakan untuk menyediakan data dengan cara mencatat data-data yang diperoleh. Tata cara yang dilakukan 
oleh Peneliti untuk mengumpulkan data dalam penelitian ini, yaitu: (1) Membaca puisi Potret Seorang Komunis Karya Sabar Anantaguna. (2) Membaca ulang puisi. mengidentifikasi dan mencatat hal-hal penting. (4) menganalisis hasil identifikasi. (5) Menyimpulkan hasil analisis.

Dalam penelitian ini, human instrumen digunakan sebagai alat bantu yang artinya Peneliti bertindak sebagai perencana, pelaksana, pengumpul data, analisis, penafsir data, dan melaporkan hasil penelitian. Setelah data terkumpul, terdapat upaya pengolahan data yang biasa dikenal dengan sebutan analisis data. Penelitian ini menggunakan teknik analisis deskriptif karena data yang diolah berupa katakata, bukan angka. Teknik analisis data deskriptif dipakai untuk menjelaskan realisme sosial dalam puisi Potret Seorang Komunis karya Sabar Anantaguna. Langkah-langkah analisis data dari penelitian ini, yakni: (1) Membaca secara sungguh-sungguh dan berulang-ulang kajian teori serta semua bahan yang mendukung objek penelitian. (2) Mengidentifikasi hal-hal yang berhubungan dengan realisme sosial dalam puisi. (3) Menganalisis data. (4) Menyimpulkan dan menyajikan hasilnya.

\section{HASIL DAN PEMBAHASAN}

Puisi Potret Seorang Komunis Karya Sabar Anantaguna memberikan penjelasan mengenai prinsip realisme sosial yang menjadi pandangan para pengarang Lekra. Puisi tersebut ditulis Sabar Anantaguna pada tanggal 6 April 1957 dalam surat kabar Harian Rakyat. Puisi tersebut termasuk puisi angkatan 45 yang bergenre elegi (mengandung ratapan dan ungkapan duka cita) dan sudah mendapatkan apresiasi besar dalam sastra realisme sosialis. Puisi tersebut lebih mementingkan isi dari pada bentuk. Puisi Potret Seorang Komunis Karya Sabar Anantaguna terdiri dari empat bait.

\section{Bait Pertama}

Adakah duka lebih duka yang kita punya

Kawan yang meninggal dan darahnya kental di pipi

Tapi kenangan kesayangan punya tempat dalam hati

Adakah tangis lebih tangis yang kita punya

Bait pertama memberikan penegasan bahwa mereka memiliki duka yang paling hebat sampai pada akhirnya tidak ada seorang pun yang bisa melebihi rintih tangis mereka atas duka yang dihadapi. Duka tersebut terjadi karena beberapa orang diantara mereka meninggal dengan tragis dan hanya meninggalkan kenangan baik di lubuk hati mereka.

\section{Bait Kedua}

\section{Badan lesu dan nafas sendat di dada \\ Tapi hasrat dan kerja berkejaran dalam waktu \\ Bila terpikir bila terasa kesadaran mencari dirinya Bila pernah ditakuti tapi juga disayangi}

Bait kedua memberi arti bahwa kondisi badan lemah tidak berdaya ketika mendapat kabar kawan meninggal dalam keadaan tragis sampai pada satu waktu terdapat banyak kepentingan tetapi harus diutamakan salah satunya. Seseorang tersebut sudah diambang batas 
kesadaran karena begitu banyak beban pikiran yang dihadapi dan seseorang itu pernah dipandang berbeda oleh orang di sekitarnya. Orang tersebut merasa bahwa dirinya dalam satu sisi pernah ditakuti. Akan tetapi, di sisi lainnya ia di sayangi.

\section{Bait Ketiga}

Bila kalah pun berlampauan dan menang akan datang

Adalah dada begitu sarat keinginan akan nyanyi

Dan apakah yang aku bisa selain hidup

Adalah bangga lebih bangga yang kita punya

Bait ketiga memberikan makna saat dirinya merasa kalah karena tidak bisa melakukan sesuatu, pada akhirnya semua kekalahan akan terlewati dan berganti dengan sebuah kemenangan yang dinanti. Jika kemenangan itu datang, menghibur hati yang sempat mati karena banyak duka yang menimpa, rasa hati ingin menyanyi, bergembira atas apa yang dibawa oleh kemenangan. Seseorang itu merasa hidup ini memilki arti dan beruntung masih mempunyai kesempatan untuk memaksimalkan apa yang ia miliki.

\section{Bait Keempat}

Di pagi manis daun berbisikan tentang komunis

Begitu lembut begitu mesra didesirkan hari biru

Adakah cinta lebih cinta yang kita punya

Sebagai kesetiaan yang berkibar di waktu kerja

Bait keempat memiliki maksud bahwa komunis menjadi primadona untuk dibicarakan pada saat itu, melihat kondisi di pagi hari sudah membicarakan tentang komunis yaitu membicarakan semua kebaikan dan hal-hal baik tentang komunis. Cinta mereka begitu besar sehingga merasa tidak ada yang dapat menyaingi rasa cinta mereka terhadap sesuatu. Cinta mereka yang kuat, melambangkan kesetian mereka terhadap komunis.

Amanat yang terkandung dalam Puisi Potret Seorang Komunis Karya Sabar Anantaguna menggambarkan bahwa kehilangan salah satu kawan terdekat menjadikan seseorang sebagai suatu bentuk kekuatan untuk membalas dendam dengan memperkuat pertahanan komunis. Dalam hal tersebut, tentu saja dibutuhkan sebuah perjuangan dan pengorbanan untuk membuahkan hasil yang diinginkan. Akan tetapi, seseorang harus melewati banyak kekalahan untuk mendapatkan itu semua.

Realisme Sosial dalam Potret Seorang Komunis karya Sabar Anantaguna yang menjadi pandangan para pengarang Lekra yaitu mereka dengan semangat perjuangannya mendukung kuat komunis di dalamnya. Lekra pernah merasa ditakuti oleh organisasi lain yang berada di sekitarnya. Lekra memandang bahwa rakyat-rakyat kecil harus bergabung di dalamnya untuk memperkuat pertahanan komunis dan memerangi organisasi bahkan memengaruhi sebuah pemerintahan. Realisme sosial dalam puisi ini sangat mengobarkan semangat juang untuk membangun dan bangkit dari sebuah kekalahan.

Dalam puisi Potret Seorang Komunis karya Sabar Anantaguna juga terdapat perbedaan perlakuan dari semua orang yang ada antara Lekra dengan masyarakat yang lainnya. Beberapa faktor yang memengaruhinya 
yaitu faktor politik, ekonomi, dan sosial. Akibat dari faktor ekonomi yaitu munculnya berbagai kelas yang saling memusuhi dan menimbulkan pertentangan kelas yang memberikan kemenangan pada kelas tertentu. Sedangkan faktor politik antara Lekra dan masyarakat pada saat itu menjadi sebuah polemik. Bahkan, Lekra menjadikan Sastra sebagai alat perang (politik) yang mana orang lain menjadikan sastra hanya sebagai tulisan dan lain sebagainya. Lekra menerbitkan banyak tulisan yang mengandung politik melalui Surat Kabar Harian Rakyat milik PKI.

Pandangan Lekra mengenai Realisme sosial yang ada di puisi Potret Seorang Komunis karya Sabar Anantaguna menerapkan sikap antisosial dari kebudayaan bukan rakyat. Lekra menyarankan untuk mempelajari pertentanganpertentangan yang terjadi di masyarakat maupun di dalam hati manusia. Hal tersebut Lekra lakukan untuk membentuk manusia baru yang memiliki segala kemampuan yang dapat memajukan dirinya dalam mengembangkan sebuah kepribadian.

Sebelum sampai pada tahap itu, Lekra melihat adanya sebuah tantangan besar untuk mengajak masyarakat bergabung dengan organisasinya, apalagi dengan keterangan bahwa Lekra merupakan bawahan dari PKI. Lekra berusaha menjanjikan bahwa organisasinya selalu menerima kritikan dari pandangan sekitarnya. Akan tetapi, mereka melanggar atau tidak merealisasikannya.

Pandangan Lekra sebagai organisasi penganut aliran realisme sosialis menyebutkan bahwa kebudayaan bukan saja tidak dapat terlepas dari politik, melainkan kebudayaan merupakan bagian dari politik. Hal tersebut menempatkan sastra hanya sebagai alat politik. Lekra juga menegaskan bahwa mereka merupakan suatu organisasi yang memperjuangkan semboyan "politik adalah panglima". Itu artinya Lekra menjadikan Sastra dan kebudayaan sebagai alat untuk sebuah pertarungan. Dengan adanya semboyan "politik adalah panglima", Bakri Siregar menyatakan bahwa seniman yang tergabung dalam Lekra harus menganut paham seni untuk rakyat dan menolak aliran seni untuk seni serta berpihak kepada rakyat. (Bahtiar, 2013). Ketetapan MPRS NO. 1/ MPRS/1960 dicetuskan dengan keluarnya Manifesto Politik Republik Indonesia (Manipol) yang menetapkan lima pokok sebagai Garis Besar Haluan Negara (GBHN) yaitu UUD 1945, Sosialisme Indonesia, Demokrasi terpimpin, Ekonomi terpimpin, dan Kepribadian Indonesia yang dikenal dengan sebutan ManipolUsdek memperbesar pengaruh PKI. Dengan dikeluarkannya Manifesto Politik Republik Indonesia dapat menguntungkan Lekra selaku organisasi yang bernaung di bawah Partai Komunisme Indonesia. Lekra menjadi sebuah organisasi yang bersifat agresif terhadap organisasi lainnya. Lekra akan menumpas individu atau organisasi yang tidak sepaham dengannya. Mereka akan melakukan berbagai cara untuk memusnahkan individu atau organisasi tersebut. Sampai pada suatu waktu, Lekra mengirimkan sebuah teror kepada banyak pengarang untuk diwajibkan bergabung dengan organisasinya atau mereka akan dihancurkan. Beberapa di antara mereka memilih bergabung karena ingin selamat dan beberapa di antaranya tetap teguh pendirian dan 
bergabung kepada partai-partai Nasionalis yang ada.

Pada 17 Agustus 1963, Manifesto kebudayaan diluncurkan sebagai reaksi terhadap segala teror yang dilakukan Lekra. Pendukung Manifestasi Kebudayaan muncul di berbagai kota. Awalnya, Lekra tidak menghawatirkan kehadiran Manifestasi kebudayaan. Akan tetapi, dengan diadakannya Konferensi Karyawan Pengarang se-Indonesia [KKPI] oleh Manifestasi Kebudayaan menyebabkan Lekra mulai melakukan berbagai serangan. Lekra pun menyebut mereka dengan "Manikebu" yang memiliki arti kurang baik. Lekra sampai memengaruhi presiden saat itu, yaitu Soekarno, akibat meluasnya Manifestasi Kebudayaan. Presiden Soekarno melarang adanya Manifestasi Kebudayaan dengan alasan Manifestasi Politik Republik sebagai pancaran pancasila telah menjadi Garis Besar Haluan Negara (GBHN) dan tidak mungkin didampingi oleh manifesto lain, terutama jika manifesto itu memberikan kesan ragu-ragu mengenai revolusi dan memberi sikap berdiri di sampingnya.

Pada saat itu, perdebatan mengenai hubungan Lekra dan komunis kerap terjadi di masyarakat yang memiliki dampak besar. Ideologi antikomunis oleh Orba telah memberikan anggapan bahwa ancaman terbesar dari suatu negara adalah komunis beserta ajarannya. Hal tersebut sangat berdampak pada aliran kesenian yang dibuat oleh Lekra yaitu Realisme Sosialis yang dipandang sebagai aliean seni "kekiri-kirian" pada masa Orde baru. Pergeseran Paradigma di mulai dari era orde baru terkait seni kerakyatan yang disambungkan dengan komunisme terlihat jelas. Hal tersebut terlihat dari catatan Watugunung, putra ketiga pelukis Sudjojono yang pernah bergabung dengan Lekra dan PKI. Watugunung mengatakan bahwa di era orde baru, baik politisi maupun budayawan harus menghindari ungkapan yang nadanya membela orang kecil, agar tidak dianggap sebagai komunis di luar dari ia penganut komunis atau bukan (Mahendra, 2020).

Lekra tidak bisa dikatakan bersih dari PKI, namun bukan bermaksud bercabang dari PKI. Kesamaan ideologi antara Lekra dan PKI memberi Lekra tempat yang terfasilitasi. Contohnya karya tulis milik seniman Lekra yang sering dimuat dalam surat Kabar Harian Rakyat milik PKI. Sebagai gantinya, Lekra menaruh dukungan dalam acaraacara kebudayaan PKI, misalnya pawai massa dan kongres. Lekra dan PKI berhubungan erat karena saling melengkapi. Setelah peristiwa Gerakan 30 September 1965 yang dibelakangi oleh PKI seluruh organisasi masyarakat dan organisasi politik yang menerima pengaruh PKI dibersihkan dan seluruh kegiatannya di hentikan. Hal ini juga berlaku bagi Lekra dan seniman yang terlibat di dalamnya (Anik, 2014). Setelah peristiwa G30SPKI layanan pemerintahan negara langsung dibersihkan dengan cara memecat dan menangkap puluhan ribu orang yang tersangka ikut terlibat dalam peristiwa G30SPKI. Pembersihan dilakukan pada semua bidang yang terkena pengaruh PKI dan semua organisasi masyarakat yang berada di bawah PKI dipaksa untuk diberhentikan.

\section{PENUTUP}

Prinsip realisme yang menjadi pandangan para pengarang Lekra dalam Potret Seorang Komunis Karya Sabar Anantaguna yaitu diperlukan 
banyak perjuangan untuk mencapai suatu tujuan walau menimbulkan beberapa problema yang didasarkan beberapa faktor yaitu faktor politik, ekonomi, dan sosial. Faktor sosial menjadi permasalahan yang cukup besar karena menimbulkan pertentangan kelas yang mengunggulkan satu kelompok. Puisi Potret Seorang Komunis Karya Sabar Anantaguna memberikan penjelasan mengenai prinsip realism sosial yang menjadi pandangan para pengarang lekra. Puisi tersebut ditulis Sabar Anantaguna pada tanggal 6 April 1957yang bergenre elegi (mengandung ratapan dan ungkapan duka cita). Amanat yang terkandung dalam dalam puisi ini yaitu menggambarkan bahwa kehilangan salah satu kawan terdekat menjadikan seseorang sebagai suatu bentuk kekuatan untuk membalas dendam dengan memperkuat perahanan komunis.

\section{DAFTAR PUSTAKA}

A innur, Syahriel. 2020. Realisme Sosial dalam Novel Bumi Manusia dan Anak Semua Bangsa Karya Pramoedya Ananta Toer. Jurnal Nosi, 8 (1). 5.

Ahmad, Pedi. 2011. Realisme Sosial Roman Larasati Karya Pramoedya Ananta Toer. Tesis. UIN Sunan Gunung Djati Bandung.

Audriana, Septian. 2018. Representasi Realitas Sosial dalam Novel Tan Karya Hendri Teja: Perspektif Realisme Sosialis Georg Lukacs. Jurnal Bapala, 5(1). 3.

Bagus, dkk. 2018. Potret kondisi Sosial Masyarakat Jawa dalam Naskah Ketoprak Klasik Gaya Surakarta. Jurnal Aksara, 30(2). 208.
Dwi dan Anik. 2014. Pelarangan BukuBuku Karya Sastrawan Lekra Tahun 1965-1968. Jurnal Avatara, 2(3). 457.

Habiba, Robby. 2018. Diskursus Estetika Realisme Sosialis: Kajian Filsafat Pendidikan Moral atas sastrawan Kreatif di Bandung. Jurnal Refleksi, 18(1). 25.

Kemal, Isthifa. 2014. Analisis Tokoh dan Penokohan dalam Hikayat Muda Balia Karya Teuku Abdullah dan M. Nasir. Jurnal Genta Mulia, 5(2). 2.

Muqoddas, Ali . 2020. Kesadaran Kelas dalam Novel seperti Dendam, Rindu Harus Dibayar Tuntas dan $O$ Karya Eka Kurniawan (Perspektif Realisme Sosialis Georg Luckas). Jurnal Diglosia, 4 (1). 50.

Pradopo, R. D. 2010. Teori Pengkajian Fiksi. Yogyakarta: Gajah Mada University Press.

Rosida dan A. Bahtiar. 2011. Sejarah Sastra. Jakarta: UIN Press

Rukayah. 2016. Menyoal Realisme Sosial dalam Novel Gadis Pantai Karya Pramoedya Ananta Toer dengan Analisis Strategi Naratif. Jurnal Publikasi Pendidikan, 6(1). 22.

Sri dan Mahendra. 2020. Dari Realitet Nasi ke Realisme Sosialis: Tema Kerakyatan dalam Seni Rupa Modern Indonesia Masa Persatuan Ahli Gambar Indonesia dan Lembaga Seni Rupa Lembaga kebudayaan Rakyat. Jurnal Historiografi, 1(1). 72. 
Suaib. 2016. Realisme Sosial dan Pertentangan Kelas Sosial dalam Novel Entrok Karya Okky Madasari. Tesis. Universitas Negeri Makassar.
Wati, Anida Rahma. 2018. Ideologi Kesadaran Kelas dalam Novel Cinta untuk Perempuan dengan Bulir-Bulir Cahaya di Wajahnya Karya Sayfullan (Kajian Maxisme). Jurnal Stilistika, 11(2). 18. 